\title{
Feminism and Its Discontents
}





\title{
Feminism and Its Discontents
}

\author{
A Century of Struggle \\ with Psychoanalysis
}

Mari Jo Buhle

Harvard University Press

Cambridge, Massachusetts

London, England

1998 
Copyright (C) 1998 by Mari Jo Buhle All rights reserved

Printed in the United States of America

Library of Congress Cataloging-in-Publication Data

Buhle, Mari Jo, 1943-

Feminism and its discontents : a century of struggle with psychoanalysis / Mari Jo Buhle.

p. $\mathrm{cm}$.

Includes bibliographical references and index.

ISBN 0-674-29868-3 (alk. paper)

1. Psychoanalysis and feminism. I. Title.

BF175.4.F45B84 1998

$150.19^{\prime} 5^{\prime} 082-\mathrm{dc} 21 \quad 97-32397$ 